\title{
SUMAŽINTO KALORINGUMO DIETOS POVEIKIS KŪNO KOMPOZICIJOS RODIKLIAMS IR KRAUJO LIPIDŲ KONCENTRACIJAI
}

\author{
Daiva Vizbaraitė, Ugnė Tamašauskaitė, Arvydas Stasiulis \\ Lietuvos kūno kultūros akademija, Kaunas, Lietuva
}

\begin{abstract}
Daiva Vizbaraitė. Biomedicinos mokslų daktarè. Lietuvos kūno kultūros akademijos Taikomosios fiziologijos ir sporto medicinos katedros docentè. Mokslinių tyrimu kryptis - mitybos ir fizinio aktyvumo poveikis sveikatai.
\end{abstract}

\section{SANTRAUKA}

Tyrimo tikslas - nustatyti sumažinto kaloringumo dietos poveiki kai kuriems kūno kompozicijos rodikliams (riebalinèms raukšlèms, procentiniam riebalu kiekiui), kūno masès indeksui (KMI), nustatyti liemens ir klubu apimčiu santyki bei ivertinti kraujo lipidu koncentracijos kitima prieš sumažinto kaloringumo dietq ir po jos.

Buvo tiriamos aštuonios sveikos moterys nuo 28 iki 46 metu, atrinktos atsitiktiniu būdu. Prieš tyrima jos pildè anketa apie gyvenimo büda, žalingus ipročius, fizin̨̆ aktyvuma. Visos moterys buvo sveikos, nerūkančios, nesportuojančios ir nevartojo svaigiuju gérimu tyrimo metu. Pusantro mènesio tris kartus per savaitę joms buvo taikoma sumažinto kaloringumo dieta (su maistu jos gaudavo $1300 \pm 100$ kcal), kitomis savaités dienomis maitinosi iprastai. Pagrindiniu maisto komponentu proporcijos atitiko rekomenduojamas. Tyrimo metu moterys registravo savo iprasta mitybos raciona.

Küno kompozicijos rodikliai (riebalinés raukšles, liemens, klubu apimtis), KMI, bendrojo cholesterolio (Bch), didelio tankio lipoproteinu cholesterolio (DTL-ch) ir triacilgliceroliu (TAG) koncentracija kraujyje buvo išmatuota prieš tyrima ir po pusantro ménesio trukusios sumažinto kaloringumo dietos. Dél sumažinto kaloringumo dietos patikimai sumažèjo tiriamuju moteru kūno masè ir KMI. Bendrosios kūno masès sumažèjimas buvo susijęs su riebalinès kūno masès sumažèjimu, nes sumažèjo procentinis riebalu kiekis ir riebaliniu raukšliu storis. Taikant sumažinto kaloringumo dieta, per pusantro ménesio kraujo lipidu (DTL-ch; Bch; TAG) koncentracija nepakito. Dèl sumažinto kaloringumo dietos tiriamuju moteru liemens ir klubu apimties santykio pokyčiai buvo nereikšmingi $(p>0,05)$. Sumažéjusi santykio reikšmé yra teigiamas rodiklis, sumažinantis širdies ir kraujagysliu ligu (ŠKL), II tipo cukrinio diabeto rizika.

Taigi dèl sumažinto kaloringumo dietos programos, trukusios pusantro mènesio (tris kartus per savaite sumažinant maisto raciono kaloringuma), patikimai sumažèjo tiriamuju KMI, procentinis riebalu kiekis ir riebalinès raukšlès. Liemens ir klubu santykio pokyčiai buvo nereikšmingi, kraujo lipidu (DTL-ch; Bch; TAG) koncentracija dèl sumažinto kaloringumo dietos programos išliko panaši.

Raktažodžiai: sumažinto kaloringumo dieta, kūno kompozicija, lipidai, kūno riebalai.

\section{IVADAS}

$\mathrm{M}$ ažejant fiziniam aktyvumui darbe ir laisvalaikiu, vartojant daug kaloringo maisto, didèja kūno masè. Toks gyvenimo būdas neišvengiamai skatina antsvorị ir nutukimą (French et al., 2001).

Nutukimą lemia per didelès energinès vertès mityba arba fizinis pasyvumas. Nutunkama, jei su maistu gaunama daugiau energijos negu išeikvojama, susidaręs energijos perteklius triacilgliceroliu (TAG) pavidalu kaupiasi riebaliniame audinyje (Lašienè, Lašas, 1998).
Didèjant kūno masei, didèja sergamumas ir mirtingumas dèl lètinių ligų. Nutukę žmonès dažniau serga išemine širdies liga, nes dẻl nutukimo sutrinka lipidų apykaita. Nutukusių žmonių kraujyje padidẻja TAG ir mažo tankio lipoproteinuc cholesterolio (MTL-ch) koncentracija, sumažeja didelio tankio lipoproteinu cholesterolio (DTLch) koncentracija. Nutukimas didina arterinès hipertenzijos pavojų. Esant antsvoriui, padideja tikimybe susirgti onkologinemis ligomis (Vasiliauskas, 2001). Ligų išsivystymo rizikai dide- 
lès reikšmès turi ir riebalų pasiskirstymas kūne. „Obuolio“ tipo nutukimas (riebalai labiau kaupiasi aplink juosmeni), daug pavojingesnis negu ,kriaušès" (riebalu perteklius labiau kaupiasi ant klubu ir šlaunų). Pilvinis nutukimas didina tikimybę susirgti cukriniu diabetu, arterine hipertenzija, insultu ir išemine širdies liga (NIH, 1998). Pilvinis nutukimas yra dažniausias metabolinio sindromo požymis (Tymontas, 2006). Metabolinis sindromas pasireiškia padidèjusia gliukozès, insulino ir TAG koncentracija kraujyje. Be to, moksliniais tyrimais nustatyta, kad maža DTL-ch koncentracija kraujyje yra susijusi su metabolinio sindromo požymiais (Hotta et al., 2000).

Kūno masei reguliuoti yra daugybẻ būdų. Tai ivairios dietos, badavimas, medikamentu ir maisto papildu vartojimas, psichoterapija, padidintas fizinis aktyvumas ir sportas, kartais taikomas netgi chirurginis gydymas. Maisto kaloringumo apribojimas taip pat yra vienas iš svorio reguliavimo būdu, kurio teigiamas poveikis kūno svoriui ir sveikatai plačiai ištirtas (Fontana et al., 2004). Vis didejantis žmonių nutukimas ir su juo susijęs sergamumas lètinèmis ligomis skatina ieškoti kelių, kaip sumažinti šią problemą. Taigi būtina ieškoti tinkamiausių būdų sprendžiant šią problemą. Keliame tokią tyrimo hipotezę: taikant sumažinto kaloringumo dietą, mažèja kūno riebalų masè ir kraujo lipidų (Bch, TAG, MTL-ch) koncentracija.

Tyrimo tikslas - nustatyti sumažinto kaloringumo dietos poveikị kai kuriems kūno kompozicijos rodikliams ir lipidų koncentracijai.

\section{TYRIMO METODIKA}

Tiriamosios: aštuonios $(\mathrm{n}=8)$ 35,5 \pm 5,6 metu moterys, atrinktos atsitiktiniu būdu. Visos tiriamosios buvo sveikos, nerūkančios, nesportuojančios ir tyrimo metu nevartojo svaigiuju gérimų Tiriamujų kūno masè — 75,7 $\pm 9,5 \mathrm{~kg}$, KMI $26,5 \pm 3,2 \mathrm{~kg} / \mathrm{m}^{2}$, kūno riebalai $-34,9 \pm 4,8 \%$.

Tyrimams atlikti buvo taikomi šie metodai:

Antropometriniai matavimai. Tiriamuju ūgis buvo matuojamas $0,1 \mathrm{~cm}$ tikslumu. Kūno masè nustatoma sveriant „Tanita body composition analyzer"svarstyklëmis ir apskaičiuojamas kūno masès indeksas $\left(\mathrm{kg} / \mathrm{m}^{2}\right)$.

Kūno riebalų kiekio apskaičiavimas. Kūno riebalu kiekis buvo nustatomas kaliperiu matuojant odos riebalines raukšles (dvigalvio raumens, trigalvio raumens, pomentinè ir antklubinè). Tiriamoji privalejo stovetti tiesiai ir atsipalaidavusi. Raukšlès matuojamos vienoje kūno pusejje. Kairès rankos nykščiu ir smiliumi suimama oda, tada atitraukiama nuo raumens. Raukšlè sugnybiama kaliperiu ir gautas rezultatas užrašomas. Ta pati vieta matuojama tris kartus. Išmatavus tris kartus, apskaičiuojamas vidutinis rezultatas. Apskaičiavus odos riebalinių raukšlių storių sumą, pagal J. V. Durnin ir J. Womersley (1974) lenteles nustatytas procentinis kūno riebalų kiekis.

Liemens ir klubų matavimas. Liemens ir klubu apimtis buvo matuojama nustatant riebalu pasiskirstymą viršutinejje ir apatinèje kūno dalyse. Liemuo matuojamas tarp apatinio šonkaulio ir klubo viršutinès dalies. Klubų apimtis matuojama per storiausią klubu vietą. Matavimas atliekamas du kartus tiriamajam iškvepiant. Apskaičiuojama vidutinė reikšmė ir užrašoma. Liemens ir klubu santykis apskaičiuojamas dalijant liemens apimti iš klubu apimties. Jei gautas santykis mažesnis už 0,8 - riebalu pasiskirstymas tolygus, nekeliantis pavojaus sveikatai. Jei didesnis - toks riebalu susikaupimas rodo medžiagu apykaitos sutrikimus, padidejja rizika susirgti širdies ir kraujagyslių ligomis.

Biocheminė kraujo analizė. Lipidų koncentracijai išmatuoti buvo imamas kapiliarinis kraujas iš rankos piršto ryte nevalgius, naudojant sterilius vienkartinius mėgintuvèlius. Kraujo mėginiuose buvo tiriama TAG, Bch ir DTL-ch koncentracija standartiniu fermentiniu metodu naudojant SPOTCHEM TM EZ Sp - 4430 ARKRAY biochemini analizatorių, pagamintą Japonijoje ir reagentus darbui su SPOTCHEM TM EZ Sp - 4430 ARKRAY biocheminiu analizatoriumi. Matuojamu reikšmių tikslumui patikrinti buvo naudojami kontroliniai mèginiai, t. y. prietaisas kalibruojamas.

Su maistu gautos energijos ir suvartotu maisto komponentų nustatymas. Tiriamujų mityba eksperimento metu buvo kontroliuojama. Prieš eksperimentą ir kas savaitę dvi paras iš eilès, per visą tyrimo laikotarpi, prašyta tiriamujų registruoti ir aprašyti suvartojamą maistą, gèrimus. Iprastinès dietos buvo laikomasi visą eksperimento laikotarpi, išskyrus tas dienas, kai tiriamosios maitinosi pagal sumažinto kaloringumo dietą.

Šie duomenys vèliau analizuojami naudojantis maisto produktų sudèties lentelèmis (Kadziauskienė ir kt., 2000). Pagal jas buvo ivertinama su maistu gaunama energija, baltymu, angliavandeniu ir riebalų kiekis, apskaičiuojamas procentinis angliavandenių, riebalų ir baltymų indèlis į su maistu gaunamos energijos kieki.

Sumažinto kaloringumo dieta. Remiantis Respublikinio mitybos centro rekomendacijomis 
ir atsižvelgiant $\mathfrak{i}$ iprastini tiriamujų racioną, buvo pasiūlyta sumažinto kaloringumo dieta (Kadziauskienè ir kt., 2000). Siūlomi maisto produktai buvo panašūs kaip ir ịprastinès dietos. Stengèmès išlaikyti rekomenduojamas pagrindiniu maisto komponentu proporcijas. Gaunamos energijos kiekis sudare $1300 \pm 100 \mathrm{kcal}$ per dieną.

Matematinè statistika. Tyrimo duomenys apdoroti Microsoft Excel for Windows programa. Buvo apskaičiuojamas tyrimo rezultatų aritmetinis vidurkis $(\overline{\mathrm{x}})$, vidutinis kvadratinis nuokrypis (S). Matavimų rezultatai prieš tyrimą ir po jo buvo palyginami naudojant Studento $t$ testą. Rezultatai laikyti statistiškai reikšmingais, jei paklaidos tikimybès reikšmè $\mathrm{p}<0,05$.

Tyrimo organizavimas. Tyrimas truko 47 dienas. Prieš eksperimentą visos tiriamosios pildè anketą apie sveikatą, gyvenimo būdą, žalingus ịpročius. Atlikti antropometriniai matavimai (išmatuotos riebalinès raukšlès, apskaičiuotas liemens ir klubų apimties santykis, KMI ir procentinis riebalu kiekis), nustatyta (Bch, TAG, DTL-ch) koncentracija kraujyje. Pusantro mènesio tris dienas per savaitę tiriamosios turejjo laikytis sumažinto kaloringumo dietos ir dvi dienas per savaitę registruoti iprastą savo maisto racioną. Po 47 dienų, t. y. po sumažinto kaloringumo dietos, vèl buvo atlikti antropometriniai matavimai (išma- tuotos riebalinės raukšlès, apskaičiuotas liemens ir klubu santykis, KMI ir procentinis riebalu kiekis) ir nustatyta (Bch, TAG, DTL-ch) koncentracija kraujyje.

\section{REZULTATAI}

Taikant sumažinto kaloringumo dietos programą, mažèjo tiriamujų moterų kūno masès indeksas (KMI) (1 pav.).

Kūno masès indekso reikšmės prieš sumažinto kaloringumo dietą ir po jos skyrèsi reikšmingai $(p<0,05)$. Prieš eksperimentą tiriamujų KMI buvo lygus $26,5 \pm 3,2 \mathrm{~kg} / \mathrm{m}^{2}$, po eksperimento $-26,0 \pm 2,2 \mathrm{~kg} / \mathrm{m}^{2}$.

Prieš eksperimentą tiriamujų riebalinių raukšliu suma buvo $105,7 \pm 21,8 \mathrm{~mm}$, po eksperimento sumažèjo iki 89,2 $\pm 20 \mathrm{~mm}(\mathrm{p}<0,05)$.

Procentinis riebalų kiekis prieš dietą buvo $34,9 \pm 4,8 \%$, po sumažinto kaloringumo dietos $32,4 \pm 4 \%(\mathrm{p}<0,05)(2$ pav. $)$.

Liemens ir klubu apimties santykis kito nereikšmingai - nuo 0,78 iki 0,77 ( 3 pav.).

Lipidų koncentracijos kitimas kraujo plazmoje. Didelio tankio lipoproteinų koncentracija tiriamuju rytiniame kraujyje reikšmingai nepakito $(p>0,05)$. Prieš mitybos kaloringumo apribojimą tiriamuju DTL-ch koncentracija rytiniame kraujyje
1 pav. Kūno masès indekso (KMI) kitimas dèl sumažinto kaloringumo dietos $(\overline{\mathbf{x}} \pm \mathbf{S})$

2 pav. Kūno riebalų procentinių reikšmiụ kitimas dèl sumažinto kaloringumo dietos $(\overline{\mathbf{x}} \pm \mathbf{S})$
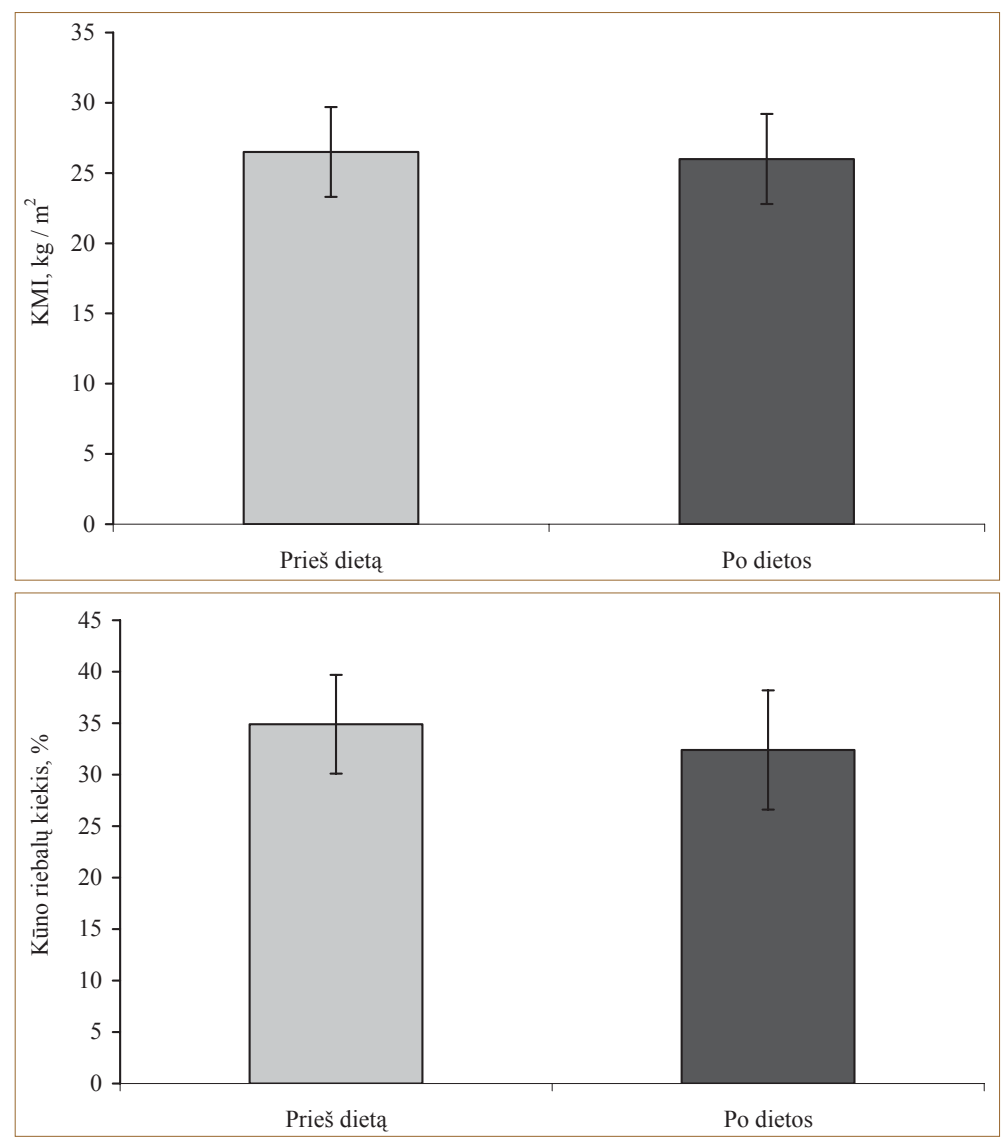

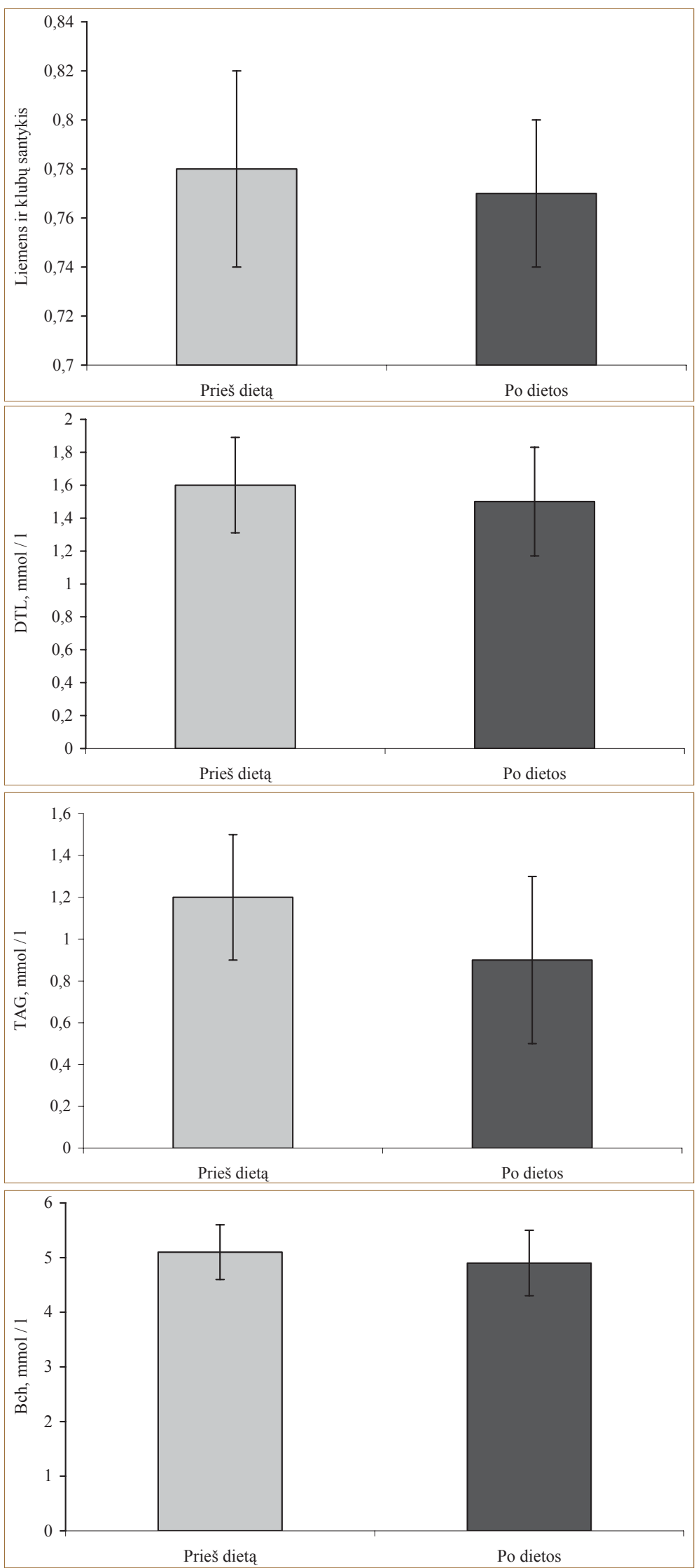

3 pav. Liemens ir klubų apimties kitimas dẻl sumažinto kaloringumo dietos $(\overline{\mathbf{x}} \pm \mathbf{S})$

4 pav. Didelio tankio lipoproteinų cholesterolio (DTL-ch) koncentracijos kitimas dèl sumažinto kaloringumo dietos $(\overline{\mathbf{x}} \pm \mathbf{S})$

5 pav. Triacilglicerolių (TAG) koncentracijos kitimas dèl sumažinto kaloringumo dietos $(\overline{\mathbf{x}} \pm \mathbf{S})$

6 pav. Bendrojo cholesterolio (Bch) koncentracijos kitimas dèl sumažinto kaloringumo dietos $(\overline{\mathbf{x}} \pm \mathbf{S})$ buvo $1,5 \mathrm{mmol} / 1$, po apribojimo $-1,6 \mathrm{mmol} / 1$ (4 pav.).

TAG koncentracija kraujyje, palyginus su pradine koncentracija prieš sumažinto kaloringumo dietą, buvo mažesnè, tačiau skirtumas nebuvo reikšmingas.

Prieš sumažinto kaloringumo dietą tiriamuju TAG koncentracija kraujyje buvo 1,2 $\mathrm{mmol} / 1$, 
po jos sumažèjo iki $0,9 \mathrm{mmol} / 1(\mathrm{p}>0,05)$ (5 pav.).

Bch koncentracija kraujyje po pusantro mėnesio sumažinto kaloringumo dietos buvo mažesnè, tačiau reikšmingai nesiskyrè.

Prieš sumažinto kaloringumo dietą tiriamuju Bch koncentracija buvo $5,1 \pm 0,3 \mathrm{mmol} / 1$, po dietos sumažèjo iki 4,9 $\pm 0,4 \mathrm{mmol} / 1(\mathrm{p}>0,05)$ (6 pav.).

\section{REZULTATU APTARIMAS}

Tiriamosioms moterims taikant sumažinto kaloringumo dietos programą, per pusantro ménesio (tris kartus per savaitę mažinant maisto raciono kaloringumą), sumažèjo kūno masè, KMI, riebalinès raukšlès, riebalinė kūno masè. Pusantro mėnesio laikotarpiu tris kartus per savaite tiriamosios su maistu gaudavo $1300 \pm 100 \mathrm{kcal}$ per diena. Pagrindinių maisto komponentu proporcijos atitiko rekomenduojamas.

Sumažinto kaloringumo dieta yra vienas pagrindinių būdų riebalinei kūno masei sumažinti, be to, ji sumažina su nutukimu susijusių komplikacijų pavojų (Li et al., 2003). Maisto kaloriju suvartojimas gali būti vienas iš svarbiausių ŠKL rizikos faktoriu (Frame et al., 1998). Dèl sumažinto kaloringumo dietos patikimai sumažèjo tiriamujų moterų kūno mase ir KMI. Yra nustatyta, kad padidejusi bendroji kūno masè arba padidejęs KMI yra tiesiogiai susiję su sergamumu ir mirtingumu dèl širdies ir kraujagyslių ligų (Frame et al., 1998). Bendrosios kūno masès sumažèjimas buvo susijęs su riebalinès kūno masès sumažèjimu, nes sumažèjo riebalinių odos raukšlių storis. Nustatyta, kad pradejjus laikytis sumažinto kaloringumo dietos, sumažèjo visų tiriamuju KMI (Fontana et al., 2004). Y. Li ir kt. tyrimo duomenimis, KMI smarkiai sumažèjo per pirmąsias šešias sumažinto kaloringumo dietos dienas, likusi laikotarpi kito lèčiau ir vienodai ( $\mathrm{Li}$ et al., 2003).

Riebalinio audinio perteklius padidina riziką susirgti ne tik ŠKL, diabetu, bet ir věžiu. C. A. Thomson ir kt. teigimu, dietos, kuriomis nèra mažinamas su maistu gaunamos energijos kiekis, antropometrinių rodiklių nepakeičia (Thomson et al., 2005).

Dèl pusantro mènesio trukusio maisto raciono kaloringumo apribojimo sumažèjo keturios tiriamujų riebalinès odos raukšlès (dvigalvio žasto raumens, trigalvio žasto raumens, pomentinè ir antklubinè). Kitų mokslininkų tyrimo duomenimis, po trijų mènesių sumažinto kaloringumo dietos smarkiai sumažèjo tiriamujų trigalvio raumens, pomentinė ir antklubinė raukšlès, tačiau pilvo riebalinė raukšlè nepakito (Cordero-MacIntyre et al., 2000). Šie rezultatai skiriasi nuo mūsų tyrimo rezultatu. Atlikto tyrimo duomenimis, visos keturios riebalinès raukšlès patikimai sumažejo dèl sumažinto kaloringumo dietos. J. Wang ir kt. teigia, kad kalorijų apribojimas gali proporcingai labiau sumažinti poodini riebalu sluoksnį distalinèse nei centrinèse kūno srityse. Kaloriju apribojimas, kartu netaikant kitų svorio mažinimo metodų, gali sumažinti nutukimo laipsni, tačiau negali pagerinti centrinių ir pakraštinių kūno riebalų pasiskirstymo santykio (Wang et al., 2002). Nors tyrimais nustatyta, kad kartu taikant ịvairias kūno masès mažinimo priemones efektyvumas yra geresnis, sumažinto kaloringumo dieta ir fiziniai pratimai yra lygiaverčiai (Racette et al., 2006).

Mokslininkai teigia, kad maisto kalorijų apribojimas yra pagrindinis veiksnys, lemiantis lipoproteinų ir lipidų koncentracijos kraujyje sumažèjimą. Jų tyrimo duomenimis, dèl maisto kalorijų apribojimo sumažeja TAG ir Bch koncentracija. Maisto kaloringumo apribojimas, esant pakankamai mitybai, gerokai sumažina aterosklerozès ir ŠKL riziką (Verdery et al., 1998). Atlikto eksperimento metu riebalinès kūno masès sumažejjimas dèl sumažinto kaloringumo dietos programos neturèjo itakos kraujo lipidu koncentracijai. TAG, Bch, DTL-ch koncentracija reikšmingai nepakito. Galbūt TAG, Bch, DTL-ch koncentracija kraujyje reikšmingai nepakito dèl per trumpo eksperimento laikotarpio - jis truko tik pusantro mènesio. Norint pagerinti lipoproteinu profili, reikètu ilgesnès trukmès poveikio. Mokslinių tyrimų duomenimis, sumažinto kaloringumo dieta, trunkanti keletą metų, sumažina Bch, MTL ir TAG koncentraciją, padidina DTL koncentracija, ir tai pasireiškia jau pirmaisiais dietos laikymosi metais. Laikantis sumažinto kaloringumo dietos, sumažeja Bch ir MTL-ch koncentracija, o DTL-ch koncentracija kraujo serume padidèja (Vizbaraitè, Malkova, 2001).

Bendrojo cholesterolio koncentracija kraujyje dèl sumažinto kaloringumo dietos taip pat nekito. Y. Li ir kt. tyrimo metu hiperlipidemiškiems nutukusiems tiriamiesiems taikant sumažinto kaloringumo dietą (1000 kcal per dieną) 14 dienų, Bch ir DTL-ch koncentracija išliko nepakitus, tačiau TAG koncentracija smarkiai sumažèjo (Li et al., 2003). DTL-ch koncentracija, mažejjant kūno masei, dèl sumažinto kaloringumo dietos pradžioje nekito, tačiau po trijų mènesių, sumažèjus kūno masei, DTL-ch padidejimas buvo akivaizdus (Zimmerman et al., 1984). Taigi J. Zimmerman ir kt. 
tyrimo metu DTL-ch pokyčiai pastebèti po triju ménesių, tad mūsų eksperimentas, trukęs tik pusantro mènesio, buvo, ko gero, per trumpas. Kitu autoriu tyrimais nustatyta, kad TAG koncentracija rytiniame kraujyje, laikantis sumažinto kaloringumo dietos, sumažejja (Fontana et al., 2004).

Liemens ir klubų apimties santykis daug tiksliau gali padeti nustatyti hipertenzijos, metabolinio sindromo, diabeto riziką negu kūno svoris ar KMI. Jei liemens ir klubų apimties santykis didesnis negu 0,8 , galima manyti, kad yra sutrikusi medžiagų apykaita, dẻl to padidèja rizika susirgti širdies ir kraujagyslių ligomis (Kochar, 1993). Atlikto tyrimo metu dèl sumažinto kaloringumo dietos sumažejo tiriamujų moterų liemens ir klubu apimtis, tačiau liemens ir klubu santykis išliko nepakitęs. Sumažejusi liemens apimtis yra teigiamas rodiklis, mažinantis ŠKL, metabolinio sindromo ir II tipo cukrinio diabeto rizika. Manoma, kad riebalinio audinio pasiskirstymas yra svarbus ŠKL rizikos veiksnys (Gallagher, 2006). Tiek bendras, tiek pilvinis nutukimas didina tikimybę susirgti ŠKL, II tipo diabetu. Be to, dèl amžiaus atsirandantis bendrasis ir pilvinis nutukimas yra susijęs su gliukozès tolerancijos sutrikimu, padidejusia TAG, Bch ir MTL-ch koncentracija.

Kiti autoriai nurodo, kad po šešiu mėnesių sumažinto kaloringumo dietos programos, tris kartus per savaitę taikant ir vaikščiojimo programą, suma- žejja moteru bendroji kūno masè, padidejja aerobinis pajègumas. Po sumažinto kaloringumo dietos kartu taikant ir vaikščiojimo programą, sumažeja tik riebalinè kūno masè, liesoji kūno masė išlieka nepakitusi. DTL-ch koncentracija padideja, o TAG sumažejja (Ryan et al., 2000). Sumažintas maisto kaloringumas, kai mityba subalansuota ir pakankama, gali padèti reguliuoti kūno masę ir sumažinti tikimybę susirgti ŠKL. Fizinis aktyvumas gali ne tik pagerinti aerobinę fizinę būklę, kuri svarbi širdies ir kraujagyslių sistemai, metabolizmui, bet ir padeti išeikvoti energijos perteklių (Redman et al., 2007).

Galbūt tyrimo rezultatams itakos turèjo per trumpai (tik pusantro mènesio) trukęs eksperimentas. Ilgesnio eksperimento metu būtu galima tikètis reikšmingu pokyčių, ypač lipidų koncentracijos rodiklių.

\section{IŠVADA}

Dèl sumažinto kaloringumo dietos programos, trukusios pusantro mènesio (tris kartus per savaitę mažinant maisto raciono kaloringumą), patikimai sumažèjo tiriamuju kūno masès indeksas, procentinis riebalu kiekis ir riebalinès raukšlès. Liemens ir klubų santykio pokyčiai dèl sumažinto kaloringumo dietos buvo nereikšmingi, nepakito ir kraujo lipidu (DTL-ch, Bch, TAG) koncentracija kraujyje.

\section{LITERATŪRA}

Cordero-MacIntyre, Z. R., Peters, W., Libanatl, C. R. et al. (2000). Effect of a weight reduction program on total body and regional body composition in obese postmenopausal women. Annals of the New York Academy of Sciences, 904, 526-535.

Durnin, J. V., Womersley, J. (1974). Body fat assesed from total body density and its estimation from thicknesses: Measurements of men and women aged from 16 to 72 years. British Journal Nutrition, 32, 77-79.

Fontana, L., Meyer, T. E., Klein, S., Holloszy, J. O. (2004). Long-term calorie restriction is highly effective in reducing the risk for atherosclerosis in humans. Proceeding of the National Academy of Sciences of the United States of America, 101 (17), 6659-6663.

Frame, L. T., Hart, R. W., Leakly, J. E. A. (1998). Caloric restriction as a mechanism mediating resistance to environmental disease. Environmental Health Perspectives, 106 (1), 312-324.

French, S. A., Story, M., Jeffery, R. W. (2001). Environmental influences on eating and physical activity. Annual Review of Public Health, 22, 309-335.

Gallagher, D. (2006). Weight loss in older women: Influences on body composition. The American Journal of Clinical Nutrition, 84, 957-958.

Hotta, K., Funahashi, T., Arita, Y. (2000). Plasma concentrations of a novel, adipose-specific protein, adiponectin, in type 2 diabetic patients. Arterioclerosis, Thromosis, and Vascular Biology, 20, 1595-1599.

Kadziauskienė, K., Bartkevičiūtè, R., Stukas, R. ir kt. (2000). Rekomenduojamos paros maistinių medžiagų ir energijos normos. Vilnius: Respublikinis mitybos centras.

Kochar, M. S. (1993). Hypertension in obese patients. Postgraduate Medicine, 94 (3), 193-195.

Lašienė, D., Lašas, D. (1998). Nutukimas ir jo gydymas. Kaunas: Naujasis lankas.

Li, Y., Bujo, H., Takahashi, K. et al. (2003). Visceral fat: Higher responsiveness of fat mass and gene expression to calorie restriction than subcutaneous fat. Experimental Biology and Medicine, 228 (10), 1118-1123.

NIH publication. (1998). Clinical guidelines on the identification, evaluation and treatment of overweight and obesity in adults: The evidence report. Bethesda, MD: National Institutes of Health. P. 4083.

Racette, S. B., Weiss, E. P., Villareal, D. T. et al. (2006). One year of caloric restriction in humans: Feasibility and effects on body composition and abdominal adipose tissue. The Journals of Gerontology Series A: Biological Sciences and Medical Sciences, (61) 943-950.

Redman, L. M., Heilborn, L. K., Martin, C. K. et al. (2007). Effect of calorie restriction with or without exercise on body composition and fat distribution. The Journal of Cli- 
nical Endocrinology and Metabolism, 92, 3865-3872.

Ryan, A. S., Nicklas, B. J., Berman, D. M., Dennis, K. E. (2000). Dietary restriction and walking reduced fat deposition in the midthigh in obese older women. The American Journal of Clinical Nutrition, 72, 708-713.

Thomson, C. A., Rock, C. L., Giuliano, A. R. et al. (2005). Longitudinal changes in body weight and body composition among women previously treated for breast Cancer consuming a high-vegetable, fruit and fiber, low-fat diet. European Journal of Nutrition, 44 (1), 18-25.

Tymontas, G. (2006). Padidejusio kūno masès indekso ir pilvinio nutukimo itaka metaboliniam sindromui išsivystyti. Medicina, 42 (2), 123-129.

Vasiliauskas, V. (2001). Nutukimas ir širdies ligos. Lietuvos bendrosios praktikos gydytojas, 4, 479-480.

Verdery, R. B., Walford, R. L (1998). Changes in plasma lipids and lipoproteins in humans during a 2-year period of dietary restriction in Biosphere 2. Archives of Internal Medicine, 27, 158 (8), 900-906.

Vizbaraite, D., Malkova, D. (2001). Mažo kaloringumo dietos itaka kūno kompozicijai ir kraujo plazmos lipidams. Lietuvos bendrosios praktikos gydytojas, 5, 120-122.

Wang, J., Laferrere, B., Thornton, J. C., Pierson, R. N., Jr Pi-Sunyer, X. F. (2002). Regional subcutaneous - fat loss inducted by caloric restriction in obese women. The North American Association for the Study of Obesity, 10, $885-890$.

Zimmerman, J., Kaufmann, N. A., Fainaru, M. et al. (1984). Effect of weight loss in moderate obesity on plasma lipoprotein and apolipoprotein levels and on high density lipoprotein composition. Journal of the American Heart Association, 4 (2), 115-123.

\title{
THE EFFECT OF CALORIE RESTRICTED DIET ON BODY COMPOSITION AND BLOOD LIPIDS CONCENTRATION
}

\author{
Daiva Vizbaraitė, Ugnė Tamašauskaitė, Arvydas Stasiulis \\ Lithuanian Academy of Physical Education, Kaunas, Lithuania
}

\begin{abstract}
The aim of this research was to measure the effect of calorie restricted diet on some indexes of body composition and lipoprotein concentration. This research was carried out to estimate the indexes of body composition (skinfold thickness, the percentage of body fat), the body mass index (BMI), waist-to-hip ratio, and the concentration of blood lipoproteins before and after calorie restricted diet.

Eight healthy women aged from 28 to 46 years participated in the research. The women where selected at random. All the participants filled in the questionnaire about their life style, harmful habits and physical activity. Participating women were healthy, non-smoking, leading a sedentary way of life and not using alcoholic beverages. For one and a half months three times a week during the research the women where on a calorie restricted diet, and they got $1300 \pm 100 \mathrm{kcal}$ with food, the other days they had regular meals. The proportions of the main nutrients coressponded to those recommended. During the research, the women registered their usual nutrition ration.

The indexes of the body composition, skinfold thickness, waist-to-hip ratio, BMI, serum total cholesterol (Tchol), high density lipoprotein cholesterol (HDL-ch), and triglyceride (TG) concentration were estimated before and after the calorie restricted diet lasting for one and a half month. The participating women's body mass and body mass index significantly decreased because of the calorie restricted diet. The decrease of the body mass was related to the decrease of fat mass, because the skinfold thickness decreased too. As the thickness of four skinfolds decreased significantly, it means that the percentage of the body fat and skinfold decreased too. After practising the calorie restricted diet for one and a half months, blood lipids (HDL-ch, Tchol, TG) concentration did not change $(\mathrm{p}>0.05)$. The waist and hip sizes decreased because of the calorie restricted diet, but waist-to-hip ratio change after the calorie restricted diet was insignificant $(p>0.05)$. The decrease of the waist size is a rather positive index, as it decreases the risk of heart diseases, type II diabetes and metabolic syndrome.

In conclusion, calorie restricted diet program lasting for one and a half months caused a decrease in body mass index, body fat mass, but did not change blood lipid concentration.
\end{abstract}

Keywords: calorie restricted diet, body composition, lipids, body fat.

Gauta 2007 m. liepos 13 d.

Received on July 13, 2007

Priimta 2007 m. lapkričio $15 \mathrm{~d}$.

Accepted on November 15, 2007
Daiva Vizbaraite

Lietuvos kūno kultūros akademija

(Lithuanian Academy of Physical Education)

Sporto g. 6, LT-44221 Kaunas

Lietuva (Lithuania)

Tel +370 37302671

E-mail d.vizbaraite@lkka.lt 